\title{
Spatial Distribution Patterns of the Populations of Two Subterranean Termites (Blattodea: Termitidae) In Eucalyptus (Myrtales: Myrtaceae) Plantations
}

\author{
Olaniyi T Alamu ${ }^{1 *}$, Francis K Ewete ${ }^{2}$, Ayangbade E Ayandokun ${ }^{1}$ and John A Ete ${ }^{1}$ \\ ${ }^{I}$ Department of Forest Conservation and Protection, Forestry Research Institute of Nigeria, \\ Ibadan, Nigeria \\ ${ }^{2}$ Department of Crop Protection and Environmental Biology, University of Ibadan, Nigeria \\ Co-authors'emails: frankewete@yahoo.co.uk; gbadeayans@yahoo.com; johnete18@gmail.com \\ *Corresponding author's e-mails: tomniyialamu@yahoo.com; alamu.ot@frin.gov.ng \\ Received 5 Jan 2021, Revised 15 Mar 2021, Accepted 21 Apr 2021, Published May 2021 \\ DOI: https://dx.doi.org/10.4314/tjs.v47i2.17
}

\begin{abstract}
The study was conducted in Afaka, Northern Guinea Savanna of Nigeria to determine the spatial distribution patterns of the populations of Ancistrotermes sp. and Microtermes sp. in Eucalyptus camaldulensis Dehnh, Eucalyptus citriodora Hook, Eucalyptus cloeziana F. and Eucalyptus tereticornis Muell plantations. Spatial distributions patterns of the two termite species populations were determined using indices such as ratios of population variance to mean, Lloyd's index, Green coefficient, Taylor power and Iwao's regression models. The values of variance to mean ratios, Lloyd's index and Green coefficient showed that the populations of both termite species had aggregated distribution pattern in all the Eucalyptus species plantations. The distribution patterns of Ancistrotermes and Microtermes differed using Taylor's and Iwao regression models. The values of $\mathrm{R}^{2}$ in Taylor's model ranged from 0.02 to 0.99 for Ancistrotermes sp. and 0.29 to 0.99 for Microtermes sp., while in Iwao's model, $\mathrm{R}^{2}$ ranged from 0.10 to 0.96 for Ancistrotermes sp. and 0.08 to 0.98 for Microtermes sp. The information provided is vital to develop a sound pest management protocol for these termite species.
\end{abstract}

Keywords: Spatial distribution, Ancistrotermes sp., Microtermes sp., Aggregated, Taylor's model, Iwao's model

\section{Introduction}

Eucalyptus, a genus of more than 500 species, belongs to the family Myrtaceae. It is one of the most valuable and widely planted hardwoods in the world (Demel 2000). More than 300 species contain volatile essential oils in their leaves, out of which about 20 species have been reported to contain high contents of 1,8-cineole used commercially for the production of essential oils in the pharmaceutical and cosmetic industries (Dhakad et al. 2018). Leaves and stem barks of different Eucalyptus species are used for the treatments of several diseases such as typhoid fever, ulcers, malarial fever, cough, stomach upset, blood sugar and skin infections in Markurdi, Nigeria (Ekhuemelo et al. 2017). Essential oils of the leaves of E. camaldulensis were used in the treatment of lung diseases, while the volatile oils were used as expectorants (Adeniyi et al. 2006).

Termites' attacks have serious negative impacts on the successful establishment of tree plantations; and are recognized as a major 
limiting factor in Eucalyptus plantation establishment in the tropics (Nair 2007). Great losses of Eucalyptus seedlings and saplings due to termites' infestations have been reported in India (Rajagopal 1982, Nair and Varma 1985, Thakur et al. 1989, Patel and Sahu 1995), China (Wylie and Floyd 1992), Malawi (Chilima 1991) and Nigeria (Alamu 2017). Generally, members of the family Termitidae, especially the subterranean foragers have been reported to cause serious damage to the roots of young Eucalyptus plants (Wilcken et al. 2002). The occurrence of different species of subterranean termites has been reported in Eucalyptus plantations in Nigeria where the foraging populations of Ancistrotermes and Microtermes species were very prominent (Alamu et al. 2018).

Throughout Africa, members of the family Termitidae to which Ancistrotermes and Microtermes species belong are considered as serious pests to crops, rangeland and forestry. Different species of Microtermes and Ancistrotermes were reported to be responsible for the destruction of range and crops in Sudan (Pearce et al. 1995), Ethiopia (Abdurahman 1990), Ghana (UNESCO 1997) and Nigeria (Wood et al. 1980, Umeh and Ivbijaro 1997). Damage caused by Ancistrotermes and Microtermes species to plants is mostly internal or subterranean (Mugerwa et al. 2014). These subterranean termites do not build epigeal mounds, and consequently, most farmers considered them not important. However, they attack plants through the roots and advances into the stem causing wilting and eventual death (Mugerwa et al. 2014).

Integrated pest management as an alternative to absolute reliance on chemical pesticides in the control of termites to reduce damage to Eucalyptus seedlings require a good knowledge of the spatial distribution of termites (dos Santos et al. 2011). Spatial distribution has been described as one of the important characteristic properties of insect population and adequate knowledge of it is required in effective sampling plan for decision making in pest management programmes
(Binns et al. 2000, Khaing et al. 2002). Sampling programmes is an important ecological tool that can be employed in population dynamics study of pests (Wilson 1994, Jarosik et al. 2003), evaluation of the pest infestation status (Arnaldo and Torres 2005) and crop loss assessment (Hughes 1996). Some of the important parameters required for the estimation of pest density for a reliable sampling procedure have been identified as the sampling unit, sampling time and sampling size (Boeve and Weiss 1998, Southwood and Henderson 2000). Despite the fact that the objectives of population sampling may differ, the development of a sampling procedure requires adequate knowledge of the spatial distribution of the populations (Binns et al. 2000, Liu et al. 2002). The use of dispersion indices for insect pests has been described to be convenient in decision making plans for insect management programme because of their easy calculation procedure and simple results provided (Darbemamieh et al. 2011).

Spatial distribution patterns of foraging populations of termites have been studied using various methods such as the nearest-neighbour technique for distance index (Korb and Linsenmair 2001), geostatistical techniques, Ripley's K function and pair correlation function for epigeal mound and subterranean population distributions (Crist 1998, Grohmann et al. 2010, Lima et al. 2015). Arifin et al (2014) reported in South Sumatra Palembang, Indonesia, the randomly distribution of epigeal mounds built by Macrotermes spp. in different landscapes. Additionally, subterranean termites have been described to exhibit aggregated spatial distribution in Eucalyptus plantations (Bezerra and Wilcken 1998, Zanetti et al. 2005) in Brazil. However, information on the spatial distribution patterns of Ancistrotermes and Microtermes species with high prevalence in Eucalyptus plantations in Nigeria (Alamu et al. 2018) are inadequate. Therefore, as a guide to embark on meaningful sampling procedure for effective management of these two subterranean termites, their spatial distribution patterns need to be properly documented. This 
Alamu et al. - Spatial distribution patterns of the populations of two subterranean termites ...

study therefore, aimed to determine the spatial distribution patterns of the populations of Ancistrotermes and Microtermes species in Eucalyptus plantations in Afaka, Kaduna State, Nigeria to provide useful information on the development of effective sampling programme as a basis for their management.

\section{Materials and Methods \\ Termite population sampling}

The study was conducted in Eucalyptus plantations in Trial Afforestation Research Station experimental plots in Afaka, Kaduna State (Longitude 10 $0^{\circ} 39^{\prime}$ 59" North and Latitude $7^{\circ} 23^{\prime} 16^{\prime \prime}$ East), Nigeria. Populations of Ancistrotermes sp. and Microtermes sp. were sampled in four Eucalyptus species (E. camaldulensis, E. cloeziana, E. citriodora and E. tereticornis) plantations using wood boards $(30 \times 20 \times 1 \mathrm{~cm})$ prepared from Terminalia ivorensis as bait. Terminalia ivorensis has been classified as a low density wood species and very susceptible to termite infestations (Owoyemi and Olaniran 2014). In each plantation, $20 \mathrm{~T}$. ivorensis wood boards were arranged along each of the two diagonal axes of $100 \times 100 \mathrm{~m}^{2}$ sampled plot at a distance of 6 $\mathrm{m}$ apart. The experiment was replicated four times in each plantation.

Each wood board was gently lifted up at 15 days after installation, and transferred separately into a polythene bag together with the termites attached to it and the soil excavated underneath the board up to a depth of $5 \mathrm{~cm}$ with the aid of a spade and a hand trowel. All the polythene bags with the contents were carried to the laboratory where termite species were sorted out and counted. The termite samples were preserved in $70 \%$ ethanol and identified in Entomology laboratories of National Horticultural Research Institute, Ibadan and Forestry Research Institute of Nigeria, Ibadan using identification keys according to Webb (1961). Identification was based on the morphology of soldier caste using a stereo binocular microscope.
Determination of the spatial distribution patterns of Ancistrotermes and Microtermes species populations

Spatial distribution patterns of the populations of Ancistrotermes and Microtermes species were classified using dispersion indices such as variance to mean ratio $\left(S^{2} / m\right)$, Lloyd's index, Green coefficient, Taylor model and Iwao's model. When the ratio of population variance to mean population density $\left(S^{2} / \mathrm{m}\right)$ is equal to $1.0,<1$ or $>1$, the distribution is random, uniform or aggregated, respectively (Feng and Nowierski 1992). A chi-square $(\chi 2)$ test was performed for the $S^{2} / m$ to determine its significant departure from 1.0 by the following equations:

$$
\begin{aligned}
& \chi^{2}=(\mathrm{n}-1) S^{2} / \mathrm{m} \ldots \ldots \\
& Z=\sqrt{ } 2 \chi^{2}-\sqrt{ }(2 \mathrm{n}-1) .
\end{aligned}
$$

Where; $\mathrm{n}=$ number of samples, $\mathrm{S}^{2}=$ mean population variance and $\mathrm{m}=$ mean population density.

When $|\mathrm{Z}|<1.96$, agreement with a random dispersion was accepted;

when $|\mathrm{Z}|<-1.96$, a uniform dispersion was suspected; and

when $|Z|>1.96$, a clumped or aggregated dispersion was accepted following the study of Elliott (1973).

\section{Determination of patchiness}

Patchiness was determined using Lloyd's index. The index was calculated as a ratio of mean population crowding $\left(m^{*}\right)$ to mean population density $(m)$. The mean population crowding $\left(m^{*}\right)$ was determined using the formula described by Southwood (1978): $m^{*}=m+\left[\left(\mathrm{S}^{2} / m\right)-1\right]$

Where; $m=$ mean density and $\mathrm{S}^{2}=$ variance.

When Lloyd's index $=1$, it indicated a random dispersion; when it was > 1, it indicated an aggregated dispersion; and when it was $<1$, it indicated uniform dispersion (Lloyd 1967).

Determination of the degree of aggregation The degree of aggregation was measured by the Green coefficient (Cx) (Green 1966), Taylor's power law (Taylor et al. 1978) and Iwao's patchiness regression (Iwao 1968). 
Green Coefficient-The Green coefficient $(\mathrm{Cx})$ was determined using the following formula described by Green (1966):

Where; $\mathrm{S}^{2}=$ popul number of termites per sample and $\Sigma \mathrm{x}=$ total number of termites. When $\mathrm{Cx}=0$, the coefficient indicated a random dispersion; and when $C x=>0-1$, it indicated an aggregated dispersion. Taylor's power law was used to model the relationship between mean and variance as:

$$
\mathrm{S}^{2}=\mathrm{am}^{\mathrm{b}}
$$

The coefficients $a$ and $b$ were estimated from the regression model: $\log \mathrm{S}^{2}=\log \mathrm{a}+\mathrm{b} \log \mathrm{m}$, where, the slope $b$ is an index of aggregation. When $\mathrm{b}<1$, it indicated a uniform distribution; when $\mathrm{b}=1$, it indicated a random dispersion; and when $\mathrm{b}>1$, it indicated aggregated distribution. Iwao's patchiness regression was used to quantify the relationship between the mean population crowding index $\left(m^{*}\right)$ and mean density $(m)$ using the following equation:

$$
\mathrm{m}^{*}=\alpha+\beta \mathrm{m}
$$

where the value of $m^{*}$ was derived from formula: $\quad m^{*}=m+\left(\mathrm{S}^{2} / m-1\right)$.

The intercept $\alpha$ is the index of basic contagion and $\beta$ is the density contagiousness coefficient, a measure of aggregation.

\section{Results}

\section{Spatial distribution patterns of Ancistrotermes and Microtermes species populations}

The values of variance to mean ratios and Lloyd's patchiness index for Ancistrotermes and Microtermes species in the four Eucalyptus species plantations were greater than 1 . The values of $\mathrm{Z}$ statistic (deviation from randomness) and Green coefficient were greater than 1.96 and zero, respectively for the two termite species in each of the Eucalyptus species plantations (Table 1). In Table 2, Taylor's power law regression analysis showed positively significant relationships between variance $\left(S^{2}\right)$ and mean population of
Ancistrotermes sp. in E. camaldulensis $\left(\mathrm{R}^{2}=\right.$ $0.98 ; \mathrm{p}=0.01)$, E. citriodora $\left(\mathrm{R}^{2}=0.96 ; \mathrm{p}=\right.$ $0.02)$ and E. cloeziana $\left(\mathrm{R}^{2}=0.99 ; \mathrm{p}=0.05\right)$ plantations. There was a weak relationship between $\log \mathrm{S}^{2}$ and $\log \mathrm{m}$ of Ancistrotermes sp. population in E. tereticornis $\left(\mathrm{R}^{2}=0.02 ; \mathrm{p}=\right.$ 0.87 ) plantation. The values of the slopes (b) for the relationships between $\log S^{2}$ and $\log m$ of Ancistrotermes sp. populations were significantly greater than 1 in E. camaldulensis $(\mathrm{b}=2.21 ; \mathrm{t}(\mathrm{cal})>\mathrm{t}(\mathrm{tab}))$, E. citriodora $(\mathrm{b}=$ $1.95 ; \mathrm{t}$ (cal.) $>\mathrm{t}(\mathrm{tab}))$ and $E$.cloeziana $(\mathrm{b}=$ 2.11; $\mathrm{t}(\mathrm{cal})>\mathrm{t}(\mathrm{tab}))$ plantations but less than 1 in E. tereticornis $(\mathrm{b}=0.18 ; \mathrm{t}(\mathrm{cal})<\mathrm{t}(\mathrm{tab}))$ plantation (Table 2).

Similarly, using Iwao's model regression analysis, there was a positive but nonsignificant $(p<0.05)$ relationship between the mean crowding and mean population of Ancistrotermes in E. camaldulensis $\left(\mathrm{R}^{2}=0.78\right.$; $\mathrm{p}=0.11)$ and E. tereticornis $\left(\mathrm{R}^{2}=0.01 ; \mathrm{p}=\right.$ $0.68)$ plantations. However, the regression analysis of the population parameters showed a significant relationship in E. citriodora $\left(\mathrm{R}^{2}=\right.$ $0.91 ; \mathrm{p}=0.04)$ and E. cloeziana $\left(\mathrm{R}^{2}=0.96 ; \mathrm{p}=\right.$ $0.02)$ plantations. The values of slope $(\beta), 4.56$, 6.28 and 9.34 recorded for Ancistrotermes in E.camaldulensis, E. citriodora and E. cloeziana plantations, respectively were significantly greater than 1 ( $\mathrm{t}$ cal $>\mathrm{t} \mathrm{tab})$. However, the value of slope, 1.42 in $E$. tereticornis was not significantly different from 1 ( $\mathrm{t} \mathrm{cal}<\mathrm{t} \mathrm{tab})$ (Table 2).

Table 3 shows that the relationships between $\log \mathrm{S}^{2}$ and $\log \mathrm{m}$ of Microtermes sp. were positively and significantly correlated in E. camaldulensis $\left(\mathrm{R}^{2}=0.99 ; \mathrm{p}=0.01\right)$ and $E$. citriodora $\left(\mathrm{R}^{2}=0.90 ; \mathrm{p}=0.05\right)$ plantations using Taylor's model. The relationship between the two parameters were not significantly correlated in E. cloeziana $\left(\mathrm{R}^{2}=\right.$ $0.29 ; \mathrm{p}=0.46)$ and E. tereticornis $\left(\mathrm{R}^{2}=0.77\right.$; $\mathrm{p}=0.12$ ) plantations. Furthermore, the values of slopes (b) observed in E. camaldulensis, $E$. citriodora and E. cloeziana were significantly greater than $1(\mathrm{t}$ cal $>\mathrm{t}$ tab) but did not differ significantly from 1 in $E$. tereticornis plantation ( $\mathrm{t}$ cal $<\mathrm{t} \mathrm{tab})$. 
Alamu et al. - Spatial distribution patterns of the populations of two subterranean termites ...

Table 1: Dispersion parameters of Ancistrotermes and Microtermes species in different Eucalyptus plantations

\begin{tabular}{|c|c|c|c|c|c|c|c|c|c|c|}
\hline \multirow{3}{*}{$\begin{array}{l}\text { Eucalyptus } \\
\text { Plantations }\end{array}$} & \multicolumn{10}{|c|}{ Dispersion parameters } \\
\hline & \multicolumn{5}{|c|}{ Ancistrotermes sp. } & \multicolumn{5}{|c|}{ Microtermes sp. } \\
\hline & $\begin{array}{l}\text { Variance } \\
\text { mean } \\
\left(\mathrm{S}^{2} / \mathrm{m}\right)\end{array}$ & $\begin{array}{r}\text { : } \\
\text { ratio }\end{array}$ & $\begin{array}{l}\text { Deviation } \\
\text { from randomness } \\
(\mathrm{Z})\end{array}$ & $\begin{array}{l}\text { Lloyd's } \\
\text { Index } \\
(\mathrm{m} * / \mathrm{m})\end{array}$ & $\begin{array}{l}\text { Green } \\
\text { coefficient } \\
(\mathrm{Cx})\end{array}$ & $\begin{array}{l}\text { Variance } \\
\text { mean } \\
\left(\mathrm{S}^{2} / \mathrm{m}\right)\end{array}$ & $\begin{array}{r}\text { : } \\
\text { ratio }\end{array}$ & $\begin{array}{l}\text { Deviation } \\
\text { from randomness } \\
\text { (Z) }\end{array}$ & $\begin{array}{l}\text { Lloyd's } \\
\text { Index } \\
(\mathrm{m} * / \mathrm{m})\end{array}$ & $\begin{array}{l}\text { Green } \\
\text { coefficient } \\
(\mathrm{Cx})\end{array}$ \\
\hline E. camaldulensis & 944.50 & & 111.85 & 3.87 & 0.09 & 1488.85 & & 290.75 & 5.69 & 0.06 \\
\hline E. citriodora & 648.52 & & 72.44 & 7.93 & 0.02 & 672.10 & & 190.87 & 8.31 & 0.10 \\
\hline E. cloeziana & 650.49 & & 147.4 & 8.54 & 0.10 & 1815.24 & & 292.51 & 7.44 & 0.20 \\
\hline E. tereticornis & 858.65 & & 182.24 & 4.71 & 0.10 & 1344.90 & & 159.60 & 7.47 & 0.04 \\
\hline
\end{tabular}

Table 2: Taylor's power law and Iwao's regression analysis for the dispersion of Ancistrotermes sp. in different Eucalyptus species plantation

\begin{tabular}{|c|c|c|c|c|c|c|c|c|c|c|c|c|}
\hline \multirow[b]{2}{*}{$\begin{array}{l}\text { Eucalyptus } \\
\text { Plantations }\end{array}$} & \multicolumn{6}{|c|}{ Taylor power law } & \multicolumn{6}{|c|}{ Iwao's regression } \\
\hline & $\log a$ & $\mathrm{~b}$ & $\mathrm{R}^{2}$ & $\mathrm{t}(\mathrm{cal})$ & $\mathrm{t}(\mathrm{tab})$ & p-value & $\alpha$ & $\beta$ & $\mathrm{R}^{2}$ & $\mathrm{t}(\mathrm{cal})$ & $\mathrm{t}(\mathrm{tab})$ & p-value \\
\hline E. camaldulensis & -0.06 & 2.21 & 0.98 & 5.36 & 4.30 & 0.01 & -0.66 & 4.56 & 0.78 & 5.11 & 4.30 & 0.11 \\
\hline E. citriodora & 0.89 & 1.95 & 0.96 & 4.39 & 4.30 & 0.02 & 93.63 & 6.28 & 0.91 & 4.53 & 4.30 & 0.04 \\
\hline E. cloeziana & 0.68 & 2.11 & 0.99 & 13.88 & 4.30 & 0.05 & -19.31 & 9.34 & 0.96 & 6.61 & 4.30 & 0.02 \\
\hline E. tereticornis & 4.87 & 0.18 & 0.02 & 0.92 & 4.30 & 0.87 & 1494.89 & 1.42 & 0.10 & 0.81 & 4.30 & 0.68 \\
\hline
\end{tabular}

Table 3: Taylor's power law and Iwao's regression analysis for the dispersion of Microtermes sp. in Eucalyptus plantations

\begin{tabular}{lllllllllllll} 
& \multicolumn{7}{c}{ Taylor power law } & \multicolumn{7}{c}{ Iwao's regression } \\
\cline { 2 - 12 } Plantation & $\mathrm{Log} \mathrm{a}$ & $\mathrm{B}$ & $\mathrm{R}^{2}$ & $\mathrm{t}(\mathrm{cal})$ & $\mathrm{t}(\mathrm{tab})$ & $\mathrm{p}$-value & $\alpha$ & $\beta$ & $\mathrm{R}^{2}$ & $\mathrm{t}(\mathrm{cal})$ & $\mathrm{t}(\mathrm{tab})$ & $\mathrm{p}$-value \\
\hline E. camaldulensis & 1.27 & 1.73 & 0.99 & 5.21 & 4.30 & 0.01 & 413.32 & 3.18 & 0.98 & 6.72 & 4.30 & 0.01 \\
E. citriodora & 1.93 & 1.41 & 0.90 & 4.89 & 4.30 & 0.05 & 335.28 & 3.12 & 0.91 & 4.92 & 4.30 & 0.04 \\
E. cloeziana & -1.49 & 2.92 & 0.29 & 5.59 & 4.30 & 0.46 & 155.18 & 1.01 & 0.08 & 0.36 & 4.30 & 0.71 \\
E. tereticornis & 2.92 & 1.08 & 0.77 & 3.18 & 4.30 & 0.12 & 1380.13 & 0.86 & 0.11 & 0.08 & 4.30 & 0.66 \\
\hline
\end{tabular}


Using Iwao's regression model for the relationship between the mean crowding and mean density of Microtermes sp., there were significantly positive relationships between the two population parameters in E. camaldulensis $\left(\mathrm{R}^{2}=0.98 ; \mathrm{p}=0.01\right)$ and $E$. citriodora $\left(\mathrm{R}^{2}=\right.$ $0.04)$ plantations. However, in E. cloeziana $\left(\mathrm{R}^{2}\right.$ $=0.08 ; \mathrm{p}=0.71)$ and E. tereticornis $\left(\mathrm{R}^{2}=0.11\right.$; $\mathrm{p}=0.66)$ plantations the relationships between mean crowding and mean density of Microtermes were not significant (Table 3). The regression also showed that values of slopes in E. camaldulensis and E. citriodora plantations were significantly greater than $1 \mathrm{t}$ cal $>\mathrm{t} \mathrm{tab}$ ). The slope values in E. cloeziana and E. tereticornis were not significantly different from 1 ( $\mathrm{t} \mathrm{cal}<\mathrm{t} \mathrm{tab})$.

\section{Discussion}

The results of variance to mean ratio, Lloyd's index and Green coefficient provided in this study indicated that Ancistrotermes and Microtermes species had aggregated dispersion in all the Eucalyptus plantations. This is similar to the reports of Bezerra and Wilcken (1998) and dos Santos et al (2011) that subterranean termites exhibited aggregated dispersion in Eucalyptus plantations. This aggregated dispersion suggests that the presence of a termite at one point leads to an increased probability of another individual termite being nearby. Termites aggregated dispersion could also be due to the release of aggregation and trail pheromones that attract other individual termites toward sources of food. Termites lay recruitment trail from the food source to the nest in a continuous manner (Reinhard and Kaib 2001). The recruitment trail is followed by more workers as well as by single soldiers. Following the course of this trail, termites build a non-branched subterranean tunnel or a gallery above ground leading to the source of food (Reinhard et al. 1997). The sternal gland is the only known source of trail pheromones in termites, and secretions of this gland are considered to function in the recruitment of nest mates from nest to feeding sites (Arab et al. 2012). Aggregated distribution had been reported in other soil insects such as wireworms, leatherjackets, Sciaridae, Bibio johannis and D. febrilis (Benefer et al. 2010).

The results of spatial distribution of Ancistrotermes and Microtermes species using Taylor's and Iwao's regression analyses showed different patterns of dispersion in different Eucalyptus plantations. This explains the reason why the use of one index is not sufficient for the determination of spatial dispersion of an organism. The uniform distribution pattern of Ancistrotermes and Microtermes species in E. tereticornis plantation using Taylor's power law and Iwao's regression models confirmed that different statistical methods produce varied results and accuracy in calculating the spatial distribution of an organism (Sedaratian et al. 2010). Taylor's power law and Iwao's regression have been widely used for evaluation of dispersion and sampling protocols for many insects (Deligeorgidis 2002). The correlation coefficient $\left(R^{2}\right)$ in Taylor's model was always higher than in Iwao's model. This suggests that the data demonstrated better fitness in Taylor's model than Iwao's model. This has been noted for many other insects and mites (Geiger and Daane 2001, Hamilton and Hepworth 2004, Sedaratian et al. 2010, Darbemamieh et al. 2011). The coefficients $a$ and $b$ derived from the Taylor's power law have been described as sources of information for the calculation of sampling size in the development of management strategies for insect pests (Buntin 1994, Young and Young 1998, MoradiVajargah et al. 2011).

\section{Conclusion}

The spatial distribution of the foraging populations of Ancistrotermes and Microtermes exhibited aggregated dispersion using ratios of variance to mean, Lloyd index and Green coefficient in Eucalyptus plantation. However, the Taylor's and Iwao's model displayed different population spatial distributions (aggregated and uniform). Therefore, it could be concluded that the spatial distributions of 
the population of Ancistrotermes and Microtermes species is not influenced by the species of Eucalyptus but on the dispersion index employed. This important ecological information about Ancistrotermes and Microtermes can be useful in the determination of optimal sample size for effective management programme.

\section{Conflict of interest}

The authors declare that they have no conflicts of interest.

\section{References}

Abdurahman A 1990 Foraging activity and control of termites in western Ethiopia. $\mathrm{PhD}$ Dissertation. London, UK: Imperial College, University of London.

Adeniyi BA, Lawal TO and Olaleye SB 2006 Antimicrobial and gastroprotective activities of Eucalyptus camaldulensis (Myrtaceae) crude extracts. J. Biol. Sci. 6(6): 1141-1145.

Alamu OT 2017 Ecology and management of termite species in Eucalyptus plantations in Afaka, Kaduna State, Nigeria. PhD Thesis University of Ibadan, Ibadan pp. 127.

Alamu OT, Ewete FK and Jimoh SO 2018 Occurrence and diversity of termite species in Eucalyptus plantations in Afaka, Kaduna State, Nigeria. J. Res. For. Wildlife Environ. 10(2): 33-38.

Arab A, Blanco YC, Costa-Leonard AM 2012 Dynamics of foraging and recruitment behavior in the subterranean termite Coptotermes gestroi (Rhinotermitidae). Psyche: A J. Entomol. 2012 Article ID 806782, 7 pp.

Arifin Z, Dahlan Z, Sabaruddin S, Irsan, C and Hartono Y 2014 Characteristics, morphometry and spatial distribution of populations of subterranean termites, Macrotermes gilvus Hagen (Isoptera: Termitidae) in the rubber plantation, land habitat managed without pesticides and chemical fertilizers. Int. J. Sci. Res. 3(4): 102-106.

Arnaldo PS and Torres LM 2005 Spatial distribution and sampling of Thaumetopoea pityocampa (Lep: Thaumetopoeidae) populations of Pinus pinaster Ait. in
Montesinho, N. Portugal. For. Ecol. Manage. 210 (1-3): 1-7.

Benefer C, Andrew P, Blackshaw R, Ellis J and Knight M 2010 The spatial distribution of phytophagous insect larvae in grassland soils. Appl. Soil Ecol. 45: 269-274.

Bezerra Jr NS and Wilcken CF 1998 Distribuicao espacial de cupins subterraneos dos generos Syntermes e Cornitermes (Isoptera: Termitidae) em plantios de eucalipto. In: Congresso Brasileiro de Entomologia, 17, Rio de Janeiro, 1998, Resumos Rio de Janeiro, Sociedade Entomologica do Brasil, p.726.

Binns MR, Nyrop JP and van der Werf W 2000 Sampling and monitoring in crop protection: the theoretical basis for developing practical decision guides. CABI Publishing, UK 304 pp.

Boeve PJ and Weiss M 1988 Spatial distribution and sampling plans with fixed levels of precision for cereal aphids (Homoptera: Aphididae) infesting spring wheat. Can. Entomol. 130: 67-77.

Buntin GD 1994 Developing a primary sampling program. In: Pedigo LP, Buntin GD (Eds.). Handbook of sampling methods for arthropods in agriculture, pp. 99, CRC, Boca Raton, FL.

Chilima CZ 1991 Termite control in young Eucalyptus plantations in Malawi using controlled release insecticides. Commonw. For. Rev. 70: 237-247.

Crist TO 1998 The spatial distribution of termites in short grass steppe: A geostatistical approach. Oecol. 114: 410-416.

Darbemamieh M, Fathipour Y and Kamali 2011 Population abundance and seasonal activity of Zetzellia pourmirzai (Acarina: Stigmaeidae) and its preys Cenopalpus irani and Bryobia rubrioculus (Acarina: Tetranychidae) in sprayed apple orchards of Kermanshah, Iran. J. Agric. Sci. Technol. 13: 143-154.

Deligeorgidis PN 2002 Predatory effect of Orius niger Wolff (Hemiptera.: Anthocoridae) on Frankliniella occidentalis (Pergande) and Thrips tabaci Lindeman (Thysanoptera.: Thripidae). J. Appl. Entomol. 126: 82-85.

Demel T 2000 The ecological effects of Eucalyptus: Ground for making wise and Information decision. Paper presented at the workshop "The Eucalyptus Dilemma", 15 
Nov. 2000, Ghion Hotel, Addis Ababa, Ethiopia, 45 pp.

Dhakad AK, Pandey VV, Beg S, Rawat JM and Singh A 2018 Biological, medicinal and toxicological significance of Eucalyptus leaf essential oil: a review. J. Sci. Food Agric. 98(3): 833-848

dos Santos A, Zanetti V, Fernandes BCF, Serrao JE and Zanuncio JC 2011 Subterranean termites (Insecta: Isoptera) sampled in sandy and sandy-clay soils at Minas Gerais Cerrado, Brazil. Sociobiology 57(3):633-641.

Ekhuemelo D, Onah G and Wuam L 2017 Evaluation of the uses of Eucalyptus species in Makurdi Local Government Area of Benue State, Nigeria. GSC Biol. and Pharm. Sci. 1(1): 25-34

Elliott JM 1973 Some methods for the statistical analysis of samples of benthic invertebrates. Ambleside, Westmorland. Great Britain: Freshwater Biological Association. Scientific Publication No. 25.

Feng MG and Nowierski RM 1992 Variation in spatial patterns of the Russian wheat aphid Homoptera: Aphididae) among small grains in the northwestern United States. Environ. Entomol. 21: 1029-1034.

Geiger CA and Daane KM 2001 Seasonal movement and sampling of the grape mealybug, Pseudococcus maritimus (Ehrhorn) (Homoptera: Pseudococcidae: developing a sampling program for San Joaquin Valley vineyards. J. Econ. Entomol. 94: 291-301.

Green RH 1966 Measurement of nonrandomness in spatial distribution. Res. Pop. Ecol. 8: 1-7.

Grohmann C, Oldeland J, Stoyan D and Linsenmair KE 2010 Multi-scale pattern analysis of a mound-building termite species. Insectes Sociaux 57: 477-486.

Hamilton AJ and Hepworth G 2004 Accounting for cluster sampling in constructing enumerative sequential sampling plans. $J$. Econ. Entomol. 97 (3): 1132-1136.

Hughes GM 1996 Incorporating spatial pattern of harmful organism into crop loss models. Crop Prot. 15: 407-421.

Iwao S 1968 A new regression method for analyzing the aggregation pattern of animal populations. Pop. Ecol. 1: 1-20.
Jarosik V, Honek A and Dixon AFG 2003 Natural enemy ravine revisited importance of sample size for determining population growth. Ecol. Entomol. 28: 85-91.

Khaing OP, Hormchan S, Jamornmarn A and Wongpiyasatid A 2002 Spatial dispersion and optimum sample size for cotton bollworm, Helicoverpa armigera (Hubner) (Lepidoptera: Noctuidae) larvae on cotton. Agric. Nat. Sci. 36: 235-241.

Korb J and Linsenmair KE 2001 The causes of spatial patterning of mounds of a funguscultivating termite: results from nearestneighbour analysis and ecological studies. Oecol. 127: 324-333.

Lima SS, Ceddia MB, Zuchello F, Aquino AMD, Mercante FM, Alves BJR, Urquiaga S, Martius C and Boddey RM 2015 Spatial variability and vitality of epigeous termite mounds in pastures of Mato Grosso Do Sul, Brazil. Revista Brasileira de Ciência do Solo 39: 49-58.

Liu C, Wang G, Wang W and Zhou S 2002 Spatial pattern of Tetranychus urticae population in apple tree garden. J. Appl. Ecol. 13: 993-996.

Lloyd M 1967 Mean crowding. J. Animal Eco. 36: 1-30.

Moradi-Vajargah M, Golizadeh A, RafieeDastjerdi H, Zalucki MP, Hassanpour M and Naseri B 2011 Population density and spatial distribution pattern of Hypera postica (Coleoptera: Curculionidae) in Ardabil, Iran. Not. Bot. Hort. Agrobot. Cluj-Napoca 39(2): 42-48.

Mugerwa S, Mpairwe D, Zziwa E, Swaans K and Peden D 2014 Integrated termite management for improved rainwater management: A synthesis of selected African experiences. NBDC Technical Report 9. Nairobi, Kenya: ILRI.

Nair KSS 2007 Tropical Forest Insect Pests Ecology, Impact, and Management. Cambridge University Press. The Edinburgh Building, Cambridge CB2 8RU, UK, 424 pp.

Nair KSS and Varma RV 1985 Some ecological aspects of the termite problem in young Eucalypt plantations in Kerala, India. For. Ecol. Manage. 12(3-4): 287-303.

Owoyemi JM and Olaniran OS 2014 Natural resistance of ten selected Nigerian wood 
Alamu et al. - Spatial distribution patterns of the populations of two subterranean termites ...

species to subterranean termites' attack. Int. J. Biol. Sci. Appl. 1(2): 35-39.

Patel M and Sahu AK 1995 Control of termite attack on some high pulp yielding trees. Indian For. 121: 295-299.

Pearce MJ, Logan JWM and Tiben A 1995 Termites (Isoptera) from the Darfur region of the Sudan with comments on their pest status. J. Arid Environ. 30: 197-206.

Rajagopal D 1982 Relative incidence of termites on exotic species of Eucalyptus in Karnataka. Myforest 18: 9-13.

Reinhard J and Kaib M 2001 Trail communication during foraging and recruitment in the subterranean termite, Reticulitermes santonensis De Feytaud (Isoptera: Rhinotermitidae). J. Insect Behav. 14: 157-171.

Reinhard J, Hertel H and Kaib M 1997 Systematic search for food in the subterranean termite Reticulitermes santonensis De Feytaud (Isoptera, Rhinotermitidae). Insect Soc. 44: 147-158.

Sedaratian A, Fathipour Y, Talebi AA and Farahani S 2010 Population density and spatial distribution pattern of Thrips tabaci (Thysanoptera: Thripidae) on different soybean varieties. J. Agric. Sci. Technol. 12: 275-288.

Southwood TRE and Henderson PA 2000 Ecological methods. $3^{\text {rd }}$ ed. Blackwell Sciences, Oxford. Pp. 593.

Southwood TRE 1978 Ecological methods with particular reference to the study of insect populations. $2^{\text {nd }}$ ed. London: Chapman and Hall. Spectrum Books Ltd, Ibadan, Nigeria. pp. 289.

Taylor LR, Woiwod IP and Perry JN 1978 The density-dependence spatial behavior and the variety of the rarity of randomness. J. Anim. Ecol. 47: 383-406.

Thakur ML, Kumar S, Negi A and Rawat DS 1989 Chemical control of termites in Eucalyptus hybrid. Indian For. 115: 733-743.

Umeh VC and Ivbijaro MF 1997 Termite abundance and damage in traditional maize- cassava intercrops in southwestern Nigeria. Int. J. Trop. Insect Sci. 17: 315-321.

UNESCO 1997 Biodiversity conservation: Traditional knowledge and modern concepts. Proceedings of UNESCO MAB regional seminar on biosphere reserves for biodiversity conservation and sustainable development in Anglophone Africa. March, 9-12. Enviro. Protectn. Agency. Accra, Ghana. 140-146.

Webb GC 1961 Keys to the genera of the African termites. Ibadan University Press. 1961; Ibadan, Nigeria.

Wilcken CF, Raetano, CG and Forti, LC 2002 Termite pests in Eucalyptus forests of Brazil. Sociobiology 40(1): 179-190.

Wilson LT 1994 Estimating abundance, impact, and interactions among arthropods in cotton agroecosystems, 475-514 p. In: Pedigo LP, Buntin GD (Eds.). Handbook of sampling methods for arthropods in agriculture. CRC Press, Boca Raton.

Wood TG, Johnson RA and Ohiagu CE 1980 Termite damage and crop loss studies in Nigeria-a review of termite (Isoptera) damage to maize and estimation of damage, loss in yield and termite (Microtermes) abundance at Mokwa. Trop. Pest Manag. 26:241-253.

Wylie FR and Floyd RB 2002 The insect threat to Eucalyptus plantations in tropical areas of Australia and Asia. In Pest Management in Tropical Forest Plantations, ed. C. Hutacharern, B. Napompeth, G Allard and FR Wylie. Bangkok: FAO Forestry Research Support Programme for Asia and the Pacific, pp. 11-17.

Young LJ and Young JH 1998 Statistical ecology: a population perspective. Kluwer Academic Publishers, Norwell, MA. 565 pp.

Zanetti R, Amaral-Castro NR, Moraes JC, Zanuncio JC, Andrade HB and Souza-Silva A 2005 Spatial distribution and sampling methodology of heartwood termite attacks (Isoptera: Rhinotermitidae) in Eucalyptus spp. plantations in the Brazilian savannah. Sociobiology 46(3): 655-665. 